\title{
HUMAN SECURITY FACTOR IN MONGOLIA'S NATIONAL SECURITY CONCEPT
}

\author{
Ambassador J.Enkhsaikhan
}

\section{Introduction}

Mongolia's national security concept and the internationally developing human security concept have many common elements. Both of them have traversed their own way to reach where they are today. Both of them try to come with answers to the realistic demands of the present day world.

The theme of this international workshop was determined while Mongolia and the United Nations were both searching for ways of implementing United Nations General Assembly resolution 53/77D, whereby the General Assembly has requested "the Secretary General and relevant United Nations bodies to provide the necessary assistance to Mongolia to strengthen its international security and nuclear-weapon-free status". Though the General Assembly resolution covers many areas of Mongolia's security concern, the Mongolian Government and UNDP agreed that bearing in mind Mongolia's comprehensive or holistic approach to its security, as reflected in the National Security Concept of Mongolia adopted by the State Great Hural (parliament) of Mongolia in June 1994, it would be quite useful to undertake a case study of human security in Mongolia not only to determine where Mongolia stands with respect to human security but also to identify the measures that could be taken to strengthen the non-military aspects of Mongolia's security in tandem with its human security.

Furthermore, both sides agreed that such a study would also benefit the international community as well, since it is increasingly turning to the human security concept as a possible approach to addressing the overwhelming majority of non-military problems.

It is believed that the workshop in Ulaanbaatar would be one of the first international meetings to make a study of human security issues of an individual country and make some recommendations for the government of that country as well as for the relevant United Nations body, in this case for UNDP.

\section{Changing in accent in security concepts}

As the Secretary General of the United Nations has reminded in April 2000, when establishing the United Nations, its founders recognized the need to fight 
on two fronts to win the battle for enduring peace: on the security front, where victory spells freedom from want. ${ }^{2}$ In the Cold War period focus on the former overshadowed the latter.

However, United Nations' 55 years of experience has vividly demonstrated that in order to attain the principles and noble objectives of the Charter of the United Nations, prevention or extinguishing the flames of armed conflicts are not enough. The search of causes of wars and conflicts is leading the international community to the conclusion that traditional approach to security is not adequate to properly address many international problems because it narrowly focuses on one, though very important, aspect of security, while not sufficiently addressing its other aspects. The last decade of the XX century that witnessed the end of the Cold War, convening of a series of United Nations sponsored conferences on specific social issues and presentation of annual UNDP sponsored Human Development Reports had vividly demonstrated that freedom from fear, even if achieved, is not enough to ensure fuller and lasting security of nations and peoples. It is increasingly realized that freedom from fear only in tandem with freedom from want could bring about more stable and lasting security for nations and peoples. Therefore, today freedom from want is just as important as freedom from fear, if not more at the dawn of this new century.

This realization had found reflection in the Secretary General's report to the Millennium Assembly of the United Nations entitled "We the peoples: the role of the United Nations in the 21st century". In this report the Secretary General specifically presents freedom from want before freedom from fear. He underlines that "we must put the people at the center of everything we do. No calling is more noble, and no responsibility greater than that of enabling men, women and children, in cities and villages around the world, to make their lives better. Only when that begins to happen will we know that globalization is indeed becoming inclusive, allowing everyone to share its opportunities.

It took the United Nations about half a century to arrive to the above conclusion. In the post World War II period, especially during the Cold War period, the concept of security has been interpreted narrowly, 'as security of territory from external aggression, or as protection of national interests in foreign policy or as a global security from the threat of nuclear holocaust'.

As the 1994 Human Development Report underlines, the superpowers were locked in an ideological struggle-fighting the Cold War all over the world. The developing nations, having won their independence only recently, were sensitive to any real or perceived threats to their fragile national identities. Thus, the Cold War atmosphere and policies overshadowed freedom from want, reflected in the Charter of the United Nations. 
The provisions of the UN Charter presupposed that external aggression, as attack by one State against another, would constitute the most serious threat. However, life has demonstrated that in recent decades far more people have been killed in civil wars, ethnic cleansing and acts of genocide. In the economic and social field, today nearly half of the world's population still has to make do on less than $\$ 2$ per day, approximately 1.2 billion people: 500 million in South Asia and 300 million in Africa-struggle on less than \$1. Millions of children go to bed hungry. Child mortality rate in many developing countries is very high. Poverty is still high in developing countries. Poverty and instability in many countries lead to military takeover or disintegration of power with all the ensuring consequences. If the number of battle deaths for all international and civil wars in the past century (up to 1987) was 38.5 million, the number of those killed by states in the same period was 151 million. Of a total world labor force of some 3 billion, 140 million workers are out of work altogether. And a quarter to a third is underemployed. These and many more acute questions need their solution. Narrow approach to security cannot give answers to these and many other acute problems.

\section{United Nations Approach to the Concept of Human Security}

The post Cold War period has changed the international security environment. Globalization, with its positive aspects as well as negative consequences, and increasing interdependence has become facts of life. This reality, as well as new security perceptions and threats that are emerging are forcing States to look a new at such notions as sovereignty, national interest, security and at national security concepts in general. As it was rightly pointed out by Mahbub up Hag, Special Advisor to the Administrator of UNDP, "we cannot meet the new threats to human security through the ideas and weapons of yesterday". ${ }^{4}$

Thus, the traditional territorial or military concept of security is gradually giving way to holistic and comprehensive approach to security. Such an approach to security comprises many different aspects, including human security aspects that focus primarily on security of people, on individual's personal protection and preservation in the widest meaning of the world. It could be said that with comprehensive approach to security gaining ground, so is the concept of human security.

To date there is no single United Nations definition or concept of Human security. The first United Nations attempt to define human security was made in the 1994 Human Development Report. It stated: "Human security means that people can exercise (their) choices safely and freely and that they can be rela- 
tively confident that the opportunities they have today will not be lost tomorrow." This definition in general catches the essence of human security.

The UNDP report, noting that human security is concerned with human life and dignity, points out to its four essential characteristics: universality, interdependence, easiness to ensure security through early prevention and its people-centered nature.

The report also makes distinction between human security and human development, pointing out that that latter is a process of widening the range of people's choices. It stresses that 'failure or limited human development leads to a backlog of human deprivation-poverty, hunger, disease or persisting disparities between ethnic communities or between regions. This backlog in access to power and economic opportunities can lead to violence. ${ }^{6}$ It also points out that when people are insecure, they become a burden on society. ${ }^{7}$ On the contrary, human security, according to the report, stresses that people should be able to take care of themselves: all people should have the opportunity to meet their most essential needs and to earn their own living. It concludes that this would set them free and help ensure that they can make a full contribution to development-their own development and that of their communities, their countries and the world. In a word, human security is a critical ingredient of participatory development. ${ }^{8}$

Having analyzed the long list of threats to human security, UNDP report has identified following seven main categories:

- Economic security

- Food security

- Environmental security

- Personal security

- Community security

- Political security

And has dealt in more detail on each of these categories. Thus according to UNDP report only about a quarter of the world's people may at present be economically secured, while the rest is not. This alone demonstrates the degree of vulnerability of the overwhelming majority of the people.

The report is also very useful since it provides selected indicators of human security, though recognizing that precise quantification of human security is virtually impossible. Thus it provides some indicators of such insecurities as food insecurity, job and income insecurity, human rights, violations, ethnic or religious conflicts, inequity and ratio of military to social spending. It is believed that UNDP is continuing to define other indicators of human security 
that would enable States, bearing in mind their specific features, to identify and determine the field and level of human security or insecurity as early warning indicators, and devise adequate response.

The Deputy Secretary General of the United Nations addressing a panel on Human Security, marking the XX anniversary of Vienna International Center in October 1999, stated: 'What do we mean by human security? We mean, in its most simple expression, all these things that men and women anywhere in the world cherish most: enough good for the family; adequate shelter; good health; schooling for the children; protection from violence whether inflicted by man or by nature; and a State which does not oppress its citizens but rules with their contest'. 9

A little earlier, the Secretary-General in his 1999 report on the activities of the organization raised the question of State sovereignty in the context of globalization and international cooperation. He not only pointed out that the State is now being widely understood to be the servant of its people, and not vice versa, but that at the same time individual sovereignty, i.e. human rights and fundamental freedoms of each individual as enshrined in the UN Charter has been enhanced by a renewed consciousness of the right of every individual to control his or her own destiny. He has also raised the question of humanitarian intervention, i.e. the question of legitimacy of an action taken by a regional organization without a United Nations mandate on the side, and the universally recognized imperative of effectively halting gross and systematic violations of human rights with grave humanitarian consequences, on the other. Correct approach to these questions would surely strengthen human security. The Secretary General has also raised the question of defining the national interest in the new century, underlining that for a growing number of challenges facing humanity, the collective interest is the national interest. ${ }^{10}$

The Secretary General's report to the Millennium Assembly could be considered as embodiment of the wider acceptance by the United Nations of the concept of human security. Not only the title of the report is entitled 'We the peoples...' but what is more important, the structure and content of the report itself places freedom from want before freedom from fear. The report, if supported in principle by the members, would surely give a strong impetus to further developing and even introducing the human security concept in international relations.

\section{Approaches of some States to Human security}

The United Nations is not alone in pursuing the human security concept. A growing number of member States of the United Nations is also accepting and 
supporting the concept of human security, as evidenced by the recent statements of various delegations at the plenary of the General Assembly, its main committees as well as subsidiary bodies. There is no doubt that the views and policies of member States regarding human security would influence the development of international concept and practice of human security as part of national and international security. From among the active promoters of the idea and concept of human security one could cite Japan, Canada and Thailand.

Japan's view of human security. Japanese Prime Minister Keizo Obuchi recently declared:"We should make the 21 st century a human-centered century." Japan sees human security as ensuring the survival and safety of people and the protection of their dignity. ${ }^{11}$ In preparation for the Millennium Summit, Japan is proposing to place a primary focus on human security and that whatever topics the Summit chooses to address, the participants ought to discuss them with a primary focus on their implication for human security and also with a view to enhancing human security of the people concerned. It believes that in the course of this century the international community has been struggling to make international relations peaceful and productive with a primary focus on the rights and interests of the State. Though human security concerns have not been ignored, the primary focus of States has been on the rights and interests of States rather than those of individuals. In Japan's view the primary concerns about human security vary with countries and regions. Thus most typically, the prevalence of poverty and the recurrence of conflicts are major human security concerns to many African countries, while climate change is the major human security concerns to small states in South Pacific. De-mining is a major security precondition for any post-conflict reconstruction in many areas from Bosnia to Cambodia and to Nicaragua. Illicit drugs pose serious threats to human security in both developed and developing countries. So does fflV/AIDS. ${ }^{12}$

Addressing the question of relationship between national security and human security, Japan believes that the latter is not an antithesis to the former. 'On the contrary, arrangements for national security deter war and defend the safety of a country's people and its territorial integrity in case deterrence fails. There is no question that arrangements and preparations for national security is a fundamental bulwark against threats to human security. ${ }^{13}$

Thailand's approach to human security. Thailand agrees that traditional concepts of security are woefully inadequate to meet the challenges faced by humankind. The very narrow scope of its definition serves as an intellectual straightjacket, which limits the ability to conceptualize and respond to new emerging threats. That is why the human security concept attempts to go be- 
yond the traditional meaning of security by addressing new issues. Security is to be people centered more that State-Centered. Human security should not be limited to 'freedom from fear' but should also address questions related to 'freedom from want'. Thailand believes that human being will begin to enjoy genuine security only if they are able to have chance to make a living, to be able to stand on their own feet, to have equal opportunities to develop their livelihoods and to make their own decisions about their future. However, it believes that it would not happen so long as people are threatened by socio-economic ills as poverty, disease, environmental degradation and other social vices including drugs. ${ }^{14}$

Canadian approach to human security. Like other countries, Canada believes that human security shifts focus from territorial security to that of the person. According to Canadian expert, human security may not supplant national security; human security is a logical expansion of the established debate about security in international affairs. Though Canada accepts the aforementioned seven UNDP criteria regarding human security, it believes that they "do not pay sufficient attention to the threats encountered by people as a result of violent conflict." 15

Addressing new threats to security, besides states as actors, Canada also emphasizes the role of the sub-state actors. As to the relationship between state security, it believes that though a nation State must secure itself and its territory before it might attend to matters of individual or societal well-being and quality of life of people, nevertheless it' does not follow that when States are secure, people are secure'. ${ }^{16}$ In addressing human security issues, Canada attaches great importance to international organizations, which could play a successful coordination role. In this connection a proposal is being made to look into the possibility of creating a UN Economic Security Council, suitable for integrating and coordinating international and national human security efforts. ${ }^{17}$ Canada believes that its primary objective as a member of UN Security Council "is to make human security-particularly the protection of civilians-the central focus of the Council's work." 18

\section{Mongolia's approach to national and human security}

Mongolia's present national security concept emerged as a logical response to the, new geopolitical, economic and social realities of the post-Cold War period, for a country located between the great powers of Russia and China, Mongolia's national security priority has been and still is ultimate national survival, the threats to which could take many forms. From the traditionalists' point of view, Mongolia's security concerns should be with possible 
military intervention or threat of it from either one of its neighbors. However, Mongolia does not have any territorial or political problems with its neighbors and it has in general good-neighborly relations with its two neighbors, as reflected in the treaties of friendly relations and cooperation with them. ${ }^{19}$ Absence of traditional threats to its security from the

Neighbors and the support by Russia and China of its foreign policy of balanced relationship with respect to them have allowed Mongolia to focus on other, the so-called non-traditional, threats to the security of its people.

The disintegration of the Soviet Union and end of Mongolia's special relations and of the political, economic and social system modeled after the Soviets brought about many radical changes. Thus, Mongolia was able to conduct its own relatively independent foreign policy based on the primacy of its own national interests. On the other hand, the loss of its economic partner, on which it depended almost entirely, led to the virtual collapse of its economy.

Thus with the collapse of the economic system and with it the working of the State, the social guarantees of the people also collapsed. In early 1990s production fell, inflation skyrocketed, unemployment appeared as a novel social and economic phenomenon and the living standard of the people fell, bringing about the rise in poverty. Street children, prostitution and other social ills become part of the present day reality.

These abrupt changes coincided with reappraisal by the Mongolians of their national interest, national security and foreign policy objectives and concepts, as well as the drawing up their national development priorities and programs. The Concept of National Security of Mongolia, adopted on 30 June 1994 reflects Mongolia's national interests and priorities, the holistic approach to its security. The concept is a result of enormous work undertaken by many ministries, agencies and experts. Having been adopted by the State Great Hural, the highest organ of State power and the supreme legislative power', ${ }^{20}$ it lays down the basis of State policy with regard to its national security.

The concept defines the national security as the status when favorable external and internal conditions are secured to ensure the vital national interests of Mongolia. It has for the first time clearly defined its vital national interests, who comprise the country's independence, sovereignty, territorial integrity, inviolability of State frontiers, relative economic independence, sustainable ecological development and national unity. ${ }^{21}$ the concept also deals with the factors affecting the national security and the ways and means of ensuring security. The main areas of the national security concerns are:

- Security of the existence of Mongolia 
- Security of the social order and of the State system

- Security of citizens' rights and freedoms

- Economic security

- Scientific and technological security

- Security of information

- Security of Mongolian civilization

- Security of population and its gene pool

- Ecological security

The concept is structured in such a way that each of the areas of national security concern is provided with a definition of security, enumeration of the external and internal factors that may affect the given category of security and the ways and means to ensure the security concerned.

The final provision of the Concept provides that taking into account the changes and trends in the global, regional and domestic situations and on the proposal of the National Security Council of Mongolia, the State Great Hural could make appropriate changes and amendments to the basic structure and content of the Concept.

The National Security Concept of Mongolia is a rich document. It is not a position paper but rather a policy paper. As provided by the legislation, law thereon requires its implementation and report. Its provisions are expected to be reflected in the State policy. The concept reflects Mongolia's broad approach to ensuring its national security. Hence the nine areas of security concern identified by Mongolia in its 1994 concept cover broad areas.

Comparison with the seven categories of security concern identified in the 1994 UNDP Human Development Report mentioned above, it could be said that in general they coincide, though not entirely. Though Mongolia's security concept does not make reference to human security, some of its provisions, especially relating to the security of citizens' rights and freedoms, the security of the population and its gene pool, and ecological security in fact deal directly with human security issues.

The concept is also reflective of Mongolia's geo-strategic location. Thus the concept is based on the leading role of the State in ensuring the national security. This role of the State is strongly underlined in every one of the 9 areas of security concern. The prohibitive approach is also prominent and strong. The emphasis is more on physical survival of the nation and preservation of the national identity. That might be fully justified. However, that should not hinder making the concept a more dynamic and creative force. Thus for example, the emphasis on individual welfare and quality of life could be strengthened. At 
present the economic security is focused almost entirely on ensuring the security of the State and its vital strategic interests and sectors. Many of the provisions are of prohibitive nature. Positive approach, i.e. on individual's economic rights and freedoms, on empowerment, on capacity building and opening wider opportunities for the individual are not sufficiently reflected. The author believes that when drawing up the economic part of the concept, excessive accent was made on the potential negative consequences of globalization and not enough on the opportunities that it could provide. Since human security concept underlines the creative potential of the individual, it is perhaps useful to reflect this in the national security concept of Mongolia. It is perhaps more relevant to Mongolia that is facing shortage of human resources, as well as the likelihood brain drain and migration of able and talented human resources.

\section{Conclusions}

The concept of national security is not something that is untouchable. Its sole goal is to ensure the national survival. UNGA resolution on Mongolia's international security and nuclear-weapon-free status is the reflection of international community's support for Mongolia's political independence and sovereignty. However, as it is rightly underlined in para. 32 of the national security concept of Mongolia, economic security represents the cornerstone of its independence and sovereignty. In this globalizing and increasingly interdependent world the economic survival is directly connected with economic, financial and scientific and technical viability of the state, with its ability to compete in the world economy and on the world market. One of the ways to promote competitiveness is to reduce human poverty, promote human security and quality of life of the people, to empower the people not only politically, but also economically. In Mongolia's case, where severe climatic condition is an additional challenge to overcoming poverty, to promoting development and human security, empowerment of the people also implies providing them with information on and means of coping with local or national calamities. These and some other ideas, connected with human security could be duly reflected in the national security concept of Mongolia without weakening its time tested main preventive provisions.

It is bearing this in mind that the author proposed the Government of Mongolia and the UNDP undertake a joint study on the ways to fully implement the ambitious poverty elimination program and enrich and strengthen the national security concept of Mongolia with positive aspects of human security. It is also being proposed that the Mongolian Government and UNDP together 
with the relevant international organizations undertake a study on increasing the economic security and economic competitiveness of Mongolia in the globalizing and increasingly interdependent world. This would represent a concrete input in implementing General Assembly resolution 53/77D.

\section{Endnotes}

1. See document $\mathrm{A} / 54 / 2000$

2. See document $A / 54 / 2000$, p. 7

3. Human Development Report. 1994. Chapter 2, p.22

4. Mahbub up Has "New Compulsions of Human Security", NGO/DPI Annual Conference, New York, 8 September 1993

5. Human Development Report. 1994. Chapter 2, p.23

6. Ibid., p. 23

7. Ibid., p. 24

8. Ibid., p. 24

9. See Press Release DSG/SM/70 of 12 October 1999

10. See Report of the Secretary-General of the UN on the work of then Organization. 1999

11. Statement by H.E. Yukio Satoh, Permanent Representative of Japan at the Informal Consultations of the General Assembly in Preparation for the Millennium Summit of the General Assembly. March 22, 1999

12. Ibid.

13. Ibid.

14. Statement by H.E. Mr. Suring Pits wans, Minister of Foreign Affairs of Thailand at the $54^{\text {th }}$ Session of the UNGA. 25 September 1999.

15. See George MacLean "Instituting and Projecting Human Security: A Canadian Perspective". Paper presented at the International Conference on Human Security in a Globalize World, Ulaanbaatar, Mongolia. 8-10 May 2000

16. See Department of Foreign Affairs and International Trade, Canada. Human Security: Safety for People in a Changing World. (April 1999), 5

17. George MacLean, p. 11

18. Interview with Paul Hein Becker, Canada World View: Building a Safer World. 7 (Spring 2000), 24

19. Mongolia concluded treaties of friendly relations and cooperation with Russia in 1993 and with China in 1994.

20. Article 20 of the Constitution of Mongolia, Ulaanbaatar, 1992 See the Concept of National Security of Mongolia, Ulaanbaatar, 1995. Para. 3 